\section{Barry Jones's science ministry scrapped as Hawke reorganizes}

Sydney

Australia's Department of Science has been scrapped. In a major reorganization of Australia's public service with a reduction of the number of ministries from 27 to 16 , science has been divided between new superportfolios. The move was the first action of Prime Minister Bob Hawke after the re-election of his Labor government on 11 July.

Apart from gains in efficiency, which Hawke estimates at A\$96 million a year, the reorganization also helps to solve his problem of pressure from the back bench for promotions. Despite the reduction in the number of ministries, the number of ministers will increase from 27 to $30 ; 16$ of them will have cabinet rank, each heading one of the mega-departments, and the remainder will be junior ministers assisting them.

Before the prime minister's announcement, the names of both Australia's flamboyant Minister for Science, Mr Barry Jones, and the Minister for Education, Senator Susan Ryan, were on a list of four ministers said to be in danger of relegation. They owe the weakness of their position to the over-representation of their centre-left faction in the old ministry

Jones was among the audience at the prime minister's press conference. What he heard was that much of the Department of Science he has headed is to be taken over by the Department of Industry, Technology and Commerce (DITAC), which will be the new home for science policy, the Commonwealth Scientific and Industrial Research Organization (CSIRO) and the Australian Nuclear Science and Technology Organization, as well as the patents and national standard divisions.

Research finance, almost certainly in the form of the Australian Research Council recommended by the recent review of Australia's research policy (see Nature 326, 431; 1987) and whose establishment was endorsed by both sides during the election campaign, is bound for a new Department of Education, Training and Employment.

Jones has said that he has no idea which job he will end up with in the new ministry. It seems certain that he will not be put in charge of DITAC, the province of Senator John Button, while Hawke has already made it clear that none of the major economic portfolios will change hands. Although Button is also a member of the 'centre-left faction', he is the leader of the government in the Senate and probably the number three man after the prime minister and the treasurer, Paul Keating.

The reorganization makes complete his takeover of the science and technology portfolio, given to Jones when Labor came to power in 1983. The technology component was annexed by Button after the previous election in 1984. Mr John Dawkins, at present Minister for Trade, is tipped for the Ministry of Education, Employment and Training.

Jones has many supporters. Both the CSIRO Staff Association and the Federation of Australian Scientific and Technological Societies have sent telegrams to the
Paris

THE French government is increasingly alarmed that France is falling behind its European partners in its ability to create new technology. With 12,000 patent applications a year in France, compared with 20,000 in the United Kingdom, 30,000 in West Germany and 60,000 in the United States, the need to turn fundamental research findings into marketable products is seen by the government as acute.

To help to redress this imbalance, the prime minister, Jacques Chirac, has announced special measures to encourage private-sector research, ranging from tax incentives to financial rewards for researchers who leave state-financed research for industry.

The problem, according to the government, is that the large state-supported research bodies (the grands organismes) not only cream off the best scientists but have fostered a closed system which has little contact with industry, either to define areas of need or to develop and commercialize spin-off from research.

To facilitate the transfer of knowledge from research centres to industry, an interministerial 'new materials' programme is now to be set up, linking defence, industry, telecommunications, the atomic energy commission (CEA) and the grands organismes, such as CNRS (the Centre Nationale de la Recherche Scientifique). The programme will operate with a FF200 million budget, provided from the respective partners' existing funds. Also, to "irrigate" the private sector, researchers will be offered the equivalent of a year's salary to leave state-supported institutes and join industry.

The Agence Nationale pour la Valorisation de la Recherche (ANVAR), a quasiautonomous non-government organization set up in 1979 to provide interestfree loans for innovative research and to encourage links between industry and

prime minister in praise of his unprecedented energy and enthusiasm as Minister for Science, as well as for his work in elevating science to the mainstream in Australia and for his advocacy of a brainbased economic recovery for the country.

Lumping science together with industry, technology and commerce is indicative of the government's continuing intention to make science pay its way. The new public service structure could work in favour of science. There will be representation in the cabinet from two separate ministers, something science never had in the previous government, in which Barry Jones was not a member of the cabinet.

Charles Morgan

\title{
France tries to create and promote new technology
}

fundamental research, is to receive a 10 per cent increase to FF917 million in its budget for $1987-88$. This is a dizzying volte face for the government, which cut ANVAR's budget by 40 per cent on coming to office last year.

Some critics are doubtful whether the 'new materials' programme will be an effective focus for collaboration between science and industry, while the 'bribing' of researchers to join industry was tried by the Socialists, only to be dropped when inadequate research resources in the private sector attracted few takers, a situation unlikely to change radically even with further tax allowances for research spending. Meanwhile, scientists in the grands organismes are waiting to see if the handouts to industry will be paid for by cuts in their own budgets when parliament reassembles in the autumn. Peter Coles

\section{AIDS tests in India New Delhi}

All foreigners, except journalists and diplomatic staffs, intending to stay for more than a year in India will now have to be tested for AIDS (acquired immune deficiency syndrome). The move, announced by the health ministry, is said by officials to be an attempt to placate foreign students, mostly from Africa, who complain that India's policy of testing students (now relaxed to apply only to newcomers) is discriminatory.

K.S.J.

\section{History of science}

London

A working party of the British University Grants Committee has produced an encouraging report on the future of the history of science in British universities, saying that it has a "service function" that has become "more, not less, important". It recommends continuation of the existing 